\title{
The Empirical Research of Factors Influencing Share of Wallet in the B2B Market
}

\author{
Aiwu Cheng, Lei Han, Cheng Cao \\ The Management Department, Xi' an Polytechnic University, Xi'an, China. \\ E-mail: cheng1955@126.com,1625352335@qq.com, caochengstudy@yahoo.com.cn
}

Received January $19^{\text {th }}, 2011$; revised March 17 $7^{\text {th }}, 2011$; accepted April $3^{\text {rd }}, 2011$.

\begin{abstract}
Share of wallet is a key factor in Customer relationship management system (CRM) which is an important application of E-business. Research has found that share of wallet is an important indicator to measure customer loyalty and customer potential value. On the basis of the existent marketing literatures, this study analyzes the variables influencing share of wallet according the traits of the B2B market. This paper brings forward interrelated hypotheses and conceptual model, then test the hypotheses with enterprises survey in the B2B market. Finally we use path analysis to find the principal factors influencing share of wallet and the relationships in them. The results of this research provide theoretical foundation to upgrade CRM management level of the B2B enterprises, and there is a certain reference value to predict share of wallet in customer lifetime value's (CLV) measurement.
\end{abstract}

Keywords: Share of Wallet, CRM, Customer Satisfaction, Customer Loyalty, CLV

\section{Introduction}

Along with the research and application of E-business, the integrated research of artificial intelligence, WEB technology and commercial model has obtained more and more values. E-business-based customer relationship management has a rapid development in recent years, and share of wallet, an important indicator to measure CRM, is taken seriously by managers. The high marketing costs and low profits result from satisfaction marketing strategies make managers begin to focus attention on share of wallet, now many markets have become a battle ground for a share of the customer's wallet [1]. Researchers have analyzed the value of share of wallet from many aspects in the area of CRM. Garland examines the strength of share of wallet as a proxy variable for measuring customer profitability, and find that it has a strong correlation with customer profitability [2]; Reinartz assert that share of wallet has a positive effect on customer retention and profitability [3]; Zeithaml treat share of wallet as a factor of customer retention [4]; Coyles and Gokey find that efforts to improve customers' share of spending and customer retention can add as much as ten times greater value to a company than focusing on retention alone [5]; Research conducted by McKinsey \&

*Financial supportwas provided the National Natural Science Foundation of China (No.70672116).
Company also supports this change in focus from retention to share of wallet. Share of wallet reflects the consumer's brand level spending in a given product category, and hence it is one way to measure behavioral loyalty, and this will help managers to measure customer loyalty and potential value [6,7]. Share of wallet begins to be an important quantitative indicator in a variety of marketing analysis.

Share of wallet is also an important factor in the measurement of customer lifetime value (CLV). Some scholars have pointed out that the CLV is directly proportional with share of wallet, and the relationship between them is positive [8]. This shows that share of wallet is useful for managers to adopt optimal strategies to improve the CLV, and provides foundation to predict CLV. Despite its importance, research on the topic is scarce. Moreover, prior research on share of wallet has been limited to understanding the relationship between satisfaction, share of wallet and customer retention. There are little studies to fix share of wallet, or directly give an estimate in accordance with experience. As an indicator of customer loyalty, share of wallet is influenced by a variety of factors. So we must analyze the factors before fix the share of wallet.

Most of the research on share of wallet has focused on the B2C market, there is little research to analyze the 
factors influencing share of wallet in the B2B market. The traits of the B2B market are different from the B2C market, so customer acquisition and retention is different too. Moreover, the factors influencing share of wallet in the B2B market is different from the B2C market. Therefore, it is necessary to study the factors influencing share of wallet in the B2B market. On the base of the existent marketing literatures, this study analyzes the variables influencing share of wallet according the traits of the B2B market. This paper brings forward interrelated hypothesis and conceptual model, then test the hypothesis with enterprises survey in the B2B market. Finally we use path analysis to find the principal factors influencing share of wallet and the relationship in them. The results of this research provide theoretical foundation to upgrade CRM management level of the B2B enterprises, and there is a certain reference value to predict share of wallet in customer lifetime value' measurement.

\section{Theoretical Background}

Share of Wallet is the percentage of a customer's expenses for a product that goes to the firm selling the product [9]. Since this concept appeared in the nineties of last century, people find it is not only an important indicator to measure CLV [2], but also a key factor to evaluate customer loyalty [10]. Through their research, Tim's team found that the leading position of the company will be surly stabilized if they improve the pocket share [11]. Therefore, many scholars focused on share of wallet and its influencing factors, and achieved a series of achievements.

Some researchers have found that there is direct relationship between share of wallet and customer satisfaction, customer loyalty. Brucae Cooil finds that the size of share of wallet depends on the baseline of satisfaction level [12]; Chris Baumann points out that loyalty is a crucial index; it affects customers' pocket share [13]. Rust's research finds that when customers' satisfaction improves, customers' loyalty and pocket share will grow as well [14].

Sabine has done some actual research on the elements which can affect customers' reservation, pocket share, visit share and loyalty; among them, the study mainly focus on the elements which are related with the convenience of purchasing, such as decision for purchase, purchase channel, acquiring of information, conveniences for sales and after sales. As the result, it shows that there are two elements affect visit share and pocket share, they are decision for purchase and convenience of purchase [15]. Fabriee did research from the perspective of service elements and customers' satisfaction, to see its contribution to pocket share [16]. Anne W. Magi studies customers' satisfaction, consumers' characteristics and the in- fluence of membership program on visit share and purchase share; therefore, it analyzes the relationship between customers' satisfaction and pocket share change [17]. Zou Peng finds that customer trust affects the size of share of wallet. He also pointed out that the loyal and habitual purchasers are high share of wallet customers which have high behavioral loyalty [18].

Demographic variables are also important factors influencing share of wallet. Baumane and his colleagues find that customer characteristics influence the distribution of share of wallet in retail banking, such as customer age, income and education [19]. Kim's team study the influence on loyalty and pocket share given from three components, merely age, income and education, meanwhile, the study also include the influence given by relationship expiration, products variation [20]. PerkinsMunn asserts that family, friends, environmental factors, service quality, perceived factors and reliability are the factors influencing share of wallet [21]. Liu Jianxin suggests that customer demand and the external environment influence the formation of share of wallet, such as promotion infection, low-priced temptation [15]. Rex Yu analyses the relationship between competitive factors and share of wallet, the results show that customer purchase amount in a company is related to the purchase amount from competitors, and this relationship is negative [22].

As pocket share means a lot to company's profit improvement, it draws more and more attention. Therefore, many documents and papers pick the topic such as study the enlargement of pocket share. It has pointed out by Charles that if companies can act on the eight measures such as to pay more respect to customers, to enhance the level of service, and to practice incentive policy, which can get higher share of pocket [23]. In Landy's study on banks, she finds that customer service charge and quality transparency can greatly affect the trust given by customers. If banks are in lack of necessary transparency in the two parts above, it will be hard for them to get the expected pocket share, that is to say, more trust given by customers, bigger share of pockets. Also, according to them, banks who have already got falling numbers for the pocket share would habitually neglect getting trust from customers [24]. Here are suggestions given by Lee $\mathrm{H}$, for those who want to maximize their customers' pocket share: try to make your clients like you and trust you. Know better of your clients, you'd better be clear about how they want to be served, push your men to satisfy your clients more actively [25].

Other scholars may find some related elements which affect pocket share when they are going through customers' purchasing motivation and other related things. For example, Paswan carried out an actual research on the relationship among customers' choice on convince stores, 
the motivation, the incentive buying; by the result, it shows that the incentive policy and preference because of familiarity can be active motivation for convenience stores, for it connects very actively on the pocket share customers spending on stores [26]. Peter's research finds that effective recognition can affect customers' share in a positive way [27]. Jenny and her team study the vertical growth of customers' share, and find that historical share can affect current customers' share in a non linear way [28]. Beth Davis-Sramek's team study the loyalty of B2B customers in retailing, according to their research customers' satisfaction can affect affection, trust and promise; however, for retailers with high pocket share, customers' satisfaction affecting emotions in a positive way, which actually create an indirect path the loyalty improving. Their study can make a great contribution since currently B2B customers analyses are in short [29].

The researches above have analyzed factors influencing share of wallet from different aspects, and that is helpful to understand the formation and change of share of wallet, it also provide theoretical foundation to forecast share of wallet. However, most of the research has focused on the B2C market, and there is little research in the B2B market. On the base of the existent marketing literatures, this study analyzes the variables influencing share of wallet according the traits of the B2B market, finds the principal factors influencing share of wallet and the relationship in them.

\section{Conceptual Model and Hypotheses}

The buyer in the B2B market is not the final consumer who purchases for meeting the needs of himself or his family. It is an individual or organization who gains profits from sales through the purchase of goods and services for production. The relationship between buyer and bargainer, the buyer's purchase motives, purchase behaviors in the B2B market are different from the final consumer market. In the B2B market, the quantity of a company's customers is less, but the purchase amount is large, the change of customer retention and share of wallet have a great impact on the company, the behaviors of key customers will affect the other customers' opinion about product quality, company credibility, and cause correlated effects. Customer purchase is for the purpose of profit, so the purchase motive is intellectual. Suppliers' production conditions, product quality, price and other objective factors have a great impact on the purchasing decision. The single purchase of large quantities which has high-risk makes the purchasing decision complex, and it takes a long time to establish a relationship on the first purchase. But when customers are satisfied with the transaction results, it is often able to form a stable trading relationship, and with the development of cooperation, they will most likely be strategic alliance partners. To conclude, share of wallet in the B2B market is related to customer satisfaction, supplier capability, trade conditions, and length of relationship. Based on the above analysis, we propose a conceptual model of this study (see Figure 1).

\subsection{Customer Satisfaction and Share of Wallet}

Customer satisfaction is a measure of how products and services supplied by a company meet or surpass customer expectation [30]. Some researchers have study the relationship between share of wallet and satisfaction.

Brucae Cooil finds that the size of share of wallet de-

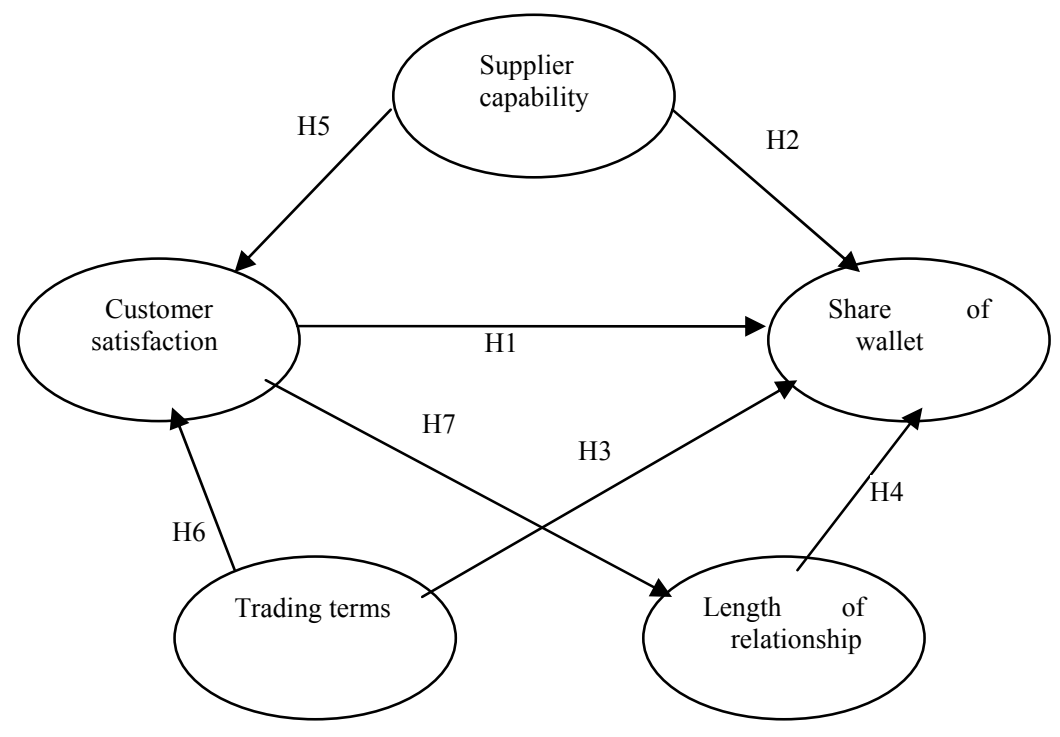

Figure 1. Conceptual model. 
pends on the baseline of satisfaction level [12]. Rust points out that customer satisfaction is good for customer retention and customer loyalty, customer satisfaction make customers stay longer, and pay a higher share of wallet [14]. Bruce Cooil's study also proves that customer satisfaction is a factor influencing share of wallet [12]. Bolton, Lemon, and Verhoef find that the customer satisfaction has a positive influence on cross-buying, so it is reasonable to suggest that the relationship between customer satisfaction and share of wallet is positive [31].

Empirical research appears to confirm the link between satisfaction and share of wallet across various industries, Researchers have found a positive relationship between satisfaction and share of wallet for the fleet trucking, pharmaceutical, institutional securities, retail banking, processed metals, and grocery retailing industries [32-35]. Customers in the B2B market purchase in order to reproduce or re-sale, so when they are satisfied with product price and quality, they will not only increase the quantity of purchasing, but also make cross-buying in order to enhance the efficiency of procurement, these acts will increase share of wallet.

Given the analysis of the relationship between customer satisfaction and share of wallet, we hypothesize the following (see Figure 1):

H1: The relationship between customer satisfaction and share of wallet is positive.

\subsection{Supplier Capability and Share of Wallet}

Related research indicates that the factors influencing customer satisfaction will indirectly influence the share of wallet, such as age, income, education, expertise, and length of relationship. Much of the research pointed out that the quality of products and services, the sensibility factors, and reliability influence the consumer's share of wallet [20]. In a B2B Environment, the Purchasing Clerks are professionals with relevant expertise. Therefore, when customers make purchase decisions, they will not only concern about the quality and reliability of products, but also pay attention to supplier capability, such as company size, technical merit, and research productivity. When supplier capability is high, the supplier could meet customer's demand better, and the customer will feel lowrisk. At the same time, high supplier capability provides conditions for centralized procurement and Cross-buying, so the share of wallet will be high. Given the above analysis, we hypothesize the following (see Figure 1):

$\mathrm{H} 2$ : The relationship between supplier capability and share of wallet is positive.

\subsection{Trading Terms and Share of Wallet}

Attitudinal loyalty has a positive impact on share of wal- let [18]. Customer trust is the foundation of customer loyalty, some related studies have proved it [36], so customer trust will also influence the size of share of wallet. Customer trust comes from the understanding and recognition to the information given by supplier, in another words, supplier provides trading terms in order to make customer feel fair, that is the basic to convince customer. In the B2B market, the buyer's professional experts have the capacity to discern product quality and price, and thus they are very sensitive to the fairness of the trade. In this case, when the seller's trading terms are fairer, the higher customer trust will be, and the customer will pay a higher share of wallet. Trading terms involve the truthfulness of information and just price. When the supplier provides full of information and reasonable price, it will get higher share of wallet. From the above discussion, we hypothesize the following (see Figure 1):

H3: Fairer trading terms are positively associated with share of wallet.

\subsection{Length of Relationship and Share of Wallet}

Rex Yu suggests that the length of relationship has linear relation with share of wallet [16]. It matches the situation in the $\mathrm{B} 2 \mathrm{~B}$ market. In the $\mathrm{B} 2 \mathrm{~B}$ market the purchasing decision is complex, the purchasing results have a great impact on the operation of company, it not only influence their competitiveness through product quality and cost, but also relate to the company's survival. Therefore, it takes them a long time to establish trading relationships with suppliers through observe, compare and select. Because purchase time costs and psychic costs are so high, once trading relationship is established, it will remain stable. With the extension of relationships, customers will be habitual loyalty through repeat purchase behavior, and customer loyalty and trust will increase share of wallet. Loyal customers prefer to realize their full purchase in the company they trust in. At the same time, if an enterprise's can provide full range of products and meet the customer's demand, customers will make the cross-purchase purchase when they make repeat purchase, thereby, that will increase the share of wallet. Given the above analysis, we hypothesize the following (see Figure 1):

H4: The relationship between length of relationship and share of wallet is positive.

\subsection{The Relationship in the Factors Influencing Share of Wallet}

Customer satisfaction is a recessive factor influencing share of wallet in the B2B market, and supplier capability, trade conditions, and length of relationship are obvious factors which correlate with recessive factor. Keininghams finds that supplier capability and trading terms 
have positive effect on customer satisfaction [20], given this, we hypothesize H5: The relationship between supplier capability and customer satisfaction is positive; H6: The relationship between trading terms and customer satisfaction is positive. Rust points out that customer satisfaction is good for customer retention, customer satisfaction make customers stay longer, and pay a higher share of wallet [18], so we hypothesize H7: The relationship between customer satisfaction and length of relationship is positive.

\section{Methodology}

\subsection{Questionnaire Design and Data Collection}

We collect empirical data through questionnaire survey to test the hypothesis. On the base of available scales in the existent marketing literatures, this study develops questionnaire according the traits of the B2B market. The scale about customer satisfaction refers to the study of Tech-Hua Ho, Young-Hoon Park and Yong-Pin Zhou [37]. The scale about trading terms refers to the study of Patricia M. Doney and Joseph P. Cannon [38]. The scale about supplier capability refers to the studies of Liu Yi, and Rust $[39,40]$. We use five-level Likert scale to measure the questions. The scale is from strongly disagreeing to strongly agree (see Table 4-1).

The date we used in this study were collected from 36 small and medium-sized enterprises in Xi'an High-tech Zone including IT, healthcare, electronics, optical and entertainment. We collected data from the companies who have CRM systems through interview in July and August of 2009. We need to interview the purchasing managers because share of wallet is a sensitive issue, we can only get an approximation. We recycle a total of 35 questionnaires, invalid questionnaires the volume are 3, effectively questionnaires volume are 32 . The returns-ratio is $91.4 \%$. Although there is only 32 questionnaires, each of the questionnaire represent a company, so the sampling representativeness is high.

\subsection{Reliability Analysis}

The design should reflect reliability and validity, and should be complete in contents, structures and forms. In this paper, we use Cronbach Alpha coefficients to test the reliability. Cronbach Alpha can take values between minus infinity and 1 (although only positive values make sense). Nunnally (1978) points out that the reliability is good if the Cronbach Alpha coefficient of the questionnaire is above 0.7 and 0.5 is the minimum acceptable level of reliability. We use "Cronbach Alpha" tool in SPSS16.0 to test the reliability. The results of calculating indicate that the Cronbach Alpha coefficient of the questionnaire is above $0.7(\alpha=0.758)$, the coefficients of all subscales were between 0.832 and 1.000 (see Table 4-1), so the questionnaire is reliable.

\subsection{Validity Analysis}

The validity includes content validity and constructs validity. Content validity is a subjective index, because the questionnaire is based on the available scales in the existent marketing literatures, it has a good content validity.

Construct validity refers to whether a scale measures or correlates with the theorized psychological construct.

It includes convergent validity and discriminant validity. We use factor analysis to test the construct validity. We put collected data into SPSS16.0 and get the test result. The KMO coefficient is 0.624 , Bartlett coefficient is 0.00 , which proves that it could make factor analysis. Four main factors whose cumulative contribution of variance accounted to $90.635 \%$ are customer satisfaction, supplier capability, trading terms and length of relationship. Factor loading for each item is above 0.6 (see Table 4-2), and they all have passed the $t$ test, significant level are all below 0.05 . Given above results, the questionnaire has a good convergent validity. As shown in Table 4-2, each item in component which it belongs to has a factor loading above 0.6 , and in components which it does not belong to, its factor loading is below 0.5 . So the ques-

Table 4-1. Questionnaire and its reliability.

\begin{tabular}{cccc}
\hline Scale & Number of terms & Cronbach Alpha & Item \\
\hline Customer satisfaction (A) & 4 & 0.95 & $\begin{array}{c}\text { Product quality (A1) } \\
\text { Service quality (A2) } \\
\text { Price (A3) }\end{array}$ \\
Product category (A4) \\
Company size (B1) \\
Technical merit (B2) \\
Research productivity (B3)
\end{tabular}


Table 4-2. Rotated component matrix.

\begin{tabular}{ccccc}
\hline & \multicolumn{3}{c}{ Component } \\
\cline { 2 - 5 } & $\begin{array}{c}\text { Customer satisfaction } \\
(\mathrm{A})\end{array}$ & $\begin{array}{c}\text { Supplier capability } \\
\text { (B) }\end{array}$ & $\begin{array}{c}\text { Trading terms } \\
\text { (C) }\end{array}$ & $\begin{array}{c}\text { Length of relationship } \\
\text { (D) }\end{array}$ \\
\hline Product quality $\left(\mathrm{A}_{1}\right)$ & 0.741 & -0.187 & 0.075 & -0.041 \\
Service quality $\left(\mathrm{A}_{2}\right)$ & 0.733 & -0.227 & 0.044 & 0.169 \\
Price $(\mathrm{A} 3)$ & 0.699 & 0.042 & 0.230 & -0.046 \\
Product category $\left(\mathrm{A}_{4}\right)$ & 0.681 & 0.356 & 0.195 & -0.075 \\
Company size $\left(\mathrm{B}_{1}\right)$ & 0.041 & 0.804 & -0.030 & 0.487 \\
Technical merit $\left(\mathrm{B}_{2}\right)$ & -0.169 & 0.770 & 0.241 & 0.270 \\
Research productivity $\left(\mathrm{B}_{3}\right)$ & 0.290 & 0.732 & -0.046 & 0.225 \\
The truthfulness of information $\left(\mathrm{C}_{1}\right)$ & 0.215 & -0.305 & 0.784 & 0.135 \\
Just price $\left(\mathrm{C}_{2}\right)$ & 0.129 & 0.418 & 0.692 & 0.232 \\
Length of relationship $\left(\mathrm{D}_{1}\right)$ & 0.122 & -0.259 & -0.046 & 1.000 \\
\hline
\end{tabular}

tionnaire has good discriminant validity. In summary, this questionnaire has good construct validity.

\section{Empirical Results}

\subsection{Correlation Analysis}

The results of correlation analysis are shown in Table 5-1. There are significant correlations between share of wallet and customer satisfaction $(P<0.01)$, trading terms $(P<0.01)$, and length of relationship $(P<0.01)$. And the correlation coefficients are $0.802,0.570$ and 0.450 , which indicates the three factors have high impact on share of wallet. However, supplier capability does not significantly related to share of wallet $(P>0.05)$ and customer satisfaction $(P>0.05)$. There are significant correlations among the other factors influencing share of wallet.

\subsection{Path Analysis}

Path analysis which can be thought of as a form of multiple regressions focusing on causality is used to describe the directed dependencies among a set of variables. In this paper, we use multiple linear regressions to make path analysis. We treat each variable in the conceptual model as dependent variable and do linear regression in order to get standardized regression coefficients which are path coefficients. The results are shown in Table 5-2, the path diagram are shown in Figure 2.

\subsection{Hypothesis Testing}

Given the above results, 5 of 7 proposed hypotheses have been supported by empirical results. The greater customer satisfaction is, the higher share of wallet is $(r=$ $0.691, p<0.01)$, so H1 is supported. Fairer trading terms are positively associated with share of wallet $(r=$ $0.229, p<0.05$ ), so $\mathrm{H} 3$ is supported.

The greater length of relationship is, the higher share of wallet is $(r=0.226, p<0.05)$, so $\mathrm{H} 3$ is supported. The three results are the main contribution of the paper.
The hypotheses from $\mathrm{H} 6$ and $\mathrm{H} 7$ are supported too.

There are only two hypotheses- $-\mathrm{H} 2$ and $\mathrm{H} 5$ get no supported (see Table 5-2).

\section{Conclusions}

In the framework of theory of share of wallet, the paper emphases key factors influencing share of wallet in a B2B environment. Customer satisfaction is the most important factor influencing share of wallet whose path coefficient is as high as 0.691 , this corresponds with the research in B2C market. Trading terms and length of relationship also positively influence share of wallet. The three main factors not only influence share of wallet directly, but also influence share of wallet indirectly by the correlativity among them. Customer satisfaction and trading terms could influence share of wallet by influencing length of relationship, and trading terms could influence share of wallet by influencing length of relationship.

The hypothesis that supplier capability is an important factor influencing share of wallet get no supported; And the hypothesis that supplier capability has a positive impact on customer satisfaction either get no supported.

The study proposes that in the B2B market customers pay most of their attention to the products and services as they allocating share of wallet which are the base of customer satisfaction. Therefore, keeping in touch with the customers in order to know the needs of customers, developing new products and services are the foundation to increase share of wallet. Giving the real and full information to customers, maintain integrity and honesty in all dealings with customers, and striving to increase the rate of customer retention are also important measures to increase share of wallet. These conclusions provide suggestions to develop CRM effectively, and have positive impact on upgrading the CLV.

Through this article did some helpful researches, there are some points that are worth to be studied. The factors influencing share of wallet include not only the four 
Table 5-1. Correlations $(* \mathrm{P}<0.01)$.

\begin{tabular}{|c|c|c|c|c|c|c|}
\hline & & $\begin{array}{c}\text { Share of } \\
\text { wallet }\end{array}$ & $\begin{array}{c}\text { Customer } \\
\text { satisfaction }\end{array}$ & $\begin{array}{l}\text { Supplier } \\
\text { capability }\end{array}$ & $\begin{array}{r}\text { Trading } \\
\text { terms }\end{array}$ & $\begin{array}{l}\text { Length of } \\
\text { relationship }\end{array}$ \\
\hline Share of wallet & Pearson Correlation & 1.000 & & & & \\
\hline $\begin{array}{l}\text { Customer satisfac- } \\
\text { tion }\end{array}$ & $\begin{array}{l}\text { Pearson Correlation } \\
\text { Sig. (2-tailed) }\end{array}$ & $\begin{array}{c}0.802 * \\
0.000\end{array}$ & 1.000 & & & \\
\hline Supplier capability & $\begin{array}{l}\text { Pearson Correlation } \\
\text { Sig. (2-tailed) }\end{array}$ & $\begin{array}{l}0.346 \\
0.053\end{array}$ & $\begin{array}{l}0.189 \\
0.299\end{array}$ & 1.000 & & \\
\hline Trading terms & $\begin{array}{l}\text { Pearson Correlation } \\
\text { Sig. (2-tailed) }\end{array}$ & $\begin{array}{c}0.570^{*} \\
0.001\end{array}$ & $\begin{array}{l}0.531 \\
0.045\end{array}$ & $\begin{array}{c}0.725^{*} \\
0.000\end{array}$ & 1.000 & \\
\hline $\begin{array}{l}\text { Length of relation- } \\
\text { ship }\end{array}$ & $\begin{array}{l}\text { Pearson Correlation } \\
\text { Sig. (2-tailed) }\end{array}$ & $\begin{array}{c}0.450^{*} \\
0.010\end{array}$ & $\begin{array}{l}0.556 \\
0.023\end{array}$ & $\begin{array}{c}0.499 * \\
0.004\end{array}$ & $\begin{array}{c}0.501^{*} \\
0.004\end{array}$ & 1.000 \\
\hline
\end{tabular}

Table 5-2. Hypothesis testing.

\begin{tabular}{|c|c|c|c|c|}
\hline & Hypothesis path & $\begin{array}{c}\text { Path coefficient } \\
(\mathrm{r})\end{array}$ & $\mathrm{P}$ & Test result \\
\hline H1 & Customer satisfaction $\rightarrow$ Share of wallet & 0.691 & 0.000 & Support \\
\hline $\mathrm{H} 2$ & Supplier capability $\rightarrow$ Share of wallet & 0.201 & 0.069 & Nonsupport \\
\hline H3 & Trading terms $\rightarrow$ Share of wallet & 0.226 & 0.041 & Support \\
\hline $\mathrm{H} 4$ & Length of relationship $\rightarrow$ Share of wallet & 0.229 & 0.031 & Support \\
\hline H5 & Supplier capability $\rightarrow$ Customer satisfaction & -0.106 & 0.679 & Nonsupport \\
\hline H6 & Trading terms $\rightarrow$ Customer satisfaction & 0.408 & 0.019 & Support \\
\hline $\mathrm{H} 7$ & Customer satisfaction $\rightarrow$ Length of relationship & 0.102 & 0.037 & Support \\
\hline
\end{tabular}

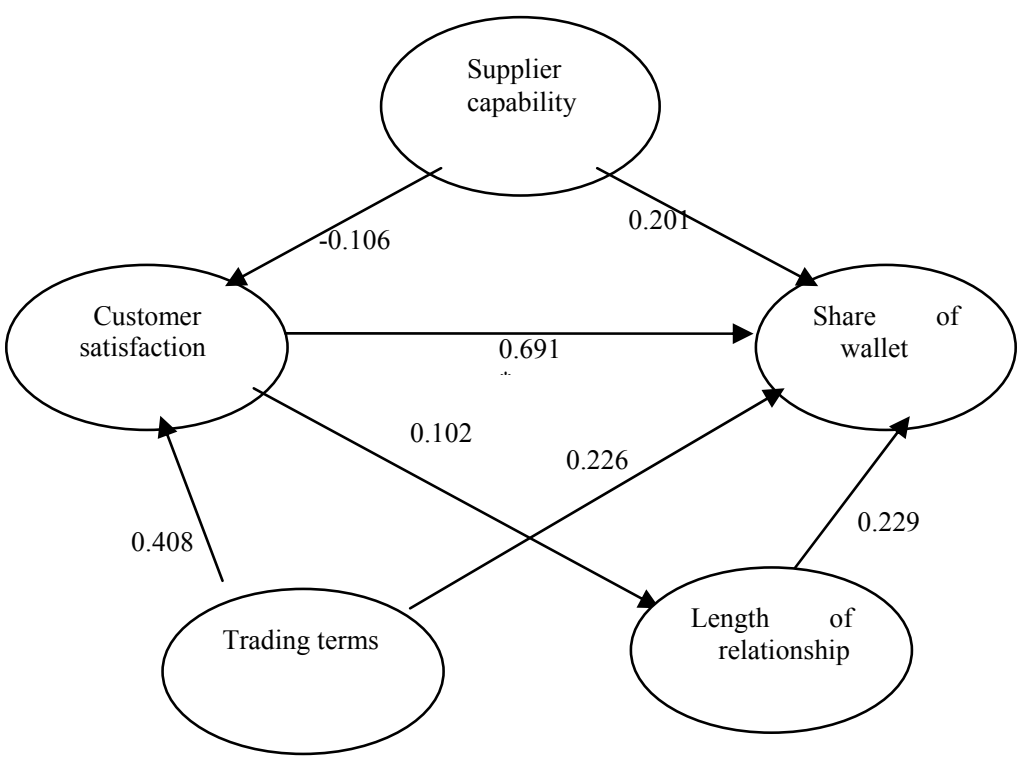

Figure 2. Path diagram $(* \mathrm{P}<0.01)$.

principal factors in this article, but also environmental factors and competitive factors which influence the buyer's purchasing decision-making. We will further discuss the model for predicting share of wallet in the B2B market in order to improve the ability of enterprises' CRM.

\section{REFERENCES}

[1] J. Wirtz, A. S. Mattila and May Oo Lwin, "How Effective are Loyalty Reward Programs in Driving Share of Wallet," Journal of Service Research, Vol. 9, No. 4, 2006, pp. 327-334. doi:10.1177/1094670506295853

[2] R. Garland, "Share of Wallet's Role in Customer Profit- 
ability," Journal of Financial Services Marketing, Vol. 8, No. 3, 2004, pp. 259-264.

doi:10.1057/palgrave.fsm.4770124

[3] W. Reinartz, J. S. Thomas and V. Kumar, "Balancing Acquisition and Retention Resources to Maximize Customer Profitability," Journal of Marketing, Vol. 69, No. 1, 2005, pp. 63-79. doi:10.1509/jmkg.69.1.63.55511

[4] V. Zeithaml, "A Service Quality, Profitability, and the Economic Worth of Customers: What We Know and What We Need to Learn," Journal of the Academy of Marketing Science, Vol. 28, No. 1, 2000, pp. 67-85. doi:10.1177/0092070300281007

[5] S. Coyles and T. C. Gokey, "Customer Retention Is Not Enough," The McKinsey Quarterly, Vol. 2, No. 2, 2002, pp. 81-89.

[6] T. L. Keiningham, L. Aksoy, B. Cooil, K. Peterson and T. G. Vavra, "A Longitudinal Examination of the Asymmetric Impact of Employee and Customer Satisfaction on Retail Sales," Managing Service Quality, Vol. 16, No. 5, 2006, pp. 42-59. doi:10.1108/09604520610686124

[7] M. D. Uncles, G. R. Dowling and K. Hammond, "Customer Loyalty and Customer Loyalty Programs," Journal of Consumer Marketing, Vol. 20, No. 4, 2003, pp. 294-316. doi:10.1108/07363760310483676

[8] T. Wang and L. Xun, "The Composition and Measurement of Customer Asset," Economic Management, Vol. 20, No. 24, 2002, pp. 48-52.

[9] J. Griffin, "Customer loyalty, How to Earn It and How to Keep It,” Jossey-Bass Publishers, San Francisco, 1995.

[10] T. O. Jones and W. E. Sasser, "Why Satisfied Customers Defect," Harvard Business Review, Vol. 73, No. 6, 1995, pp. 88-99.

[11] T. Coltman, J. Gattorna and S. Whiting, "Realigning Service Operations Strategy at DHL Express," Interfaces, Vol. 40, No. 3, 2010, pp. 175-183. doi:10.1287/inte.1100.0491

[12] B. Cooil, T. L. Keiningham, A. Lerzan and M. Hsu, "A Longitudinal Analysis of Customer Satisfaction and Share of Wallet: Investigating the Moderating Effect of Customer Characteristics," American Marketing Association Journal of Marketing, Vol. 71, No.1, 2007, pp. 67-83. doi:10.1509/jmkg.71.1.67

[13] B. Chris, S. Burton and G. Elliott, "Determinants of Customer Loyalty and Share of Wallet in Retail Banking," Journal of Financial Services Marketing, Vol. 9, No. 3, 2005, pp. 231-248. doi:10.1057/palgrave.fsm.4770156

[14] R. T. Rust, C. Moorman and P. R. Dickson, "Getting Return on Quality: Cost Reduction, Revenue Expansion, or Both?" Journal of Marketing, Vol. 66, No. 4, 2002, pp. 7-24. doi:10.1509/jmkg.66.4.7.18515

[15] S. Moeller, M. Fassnacht and A. Ettinger, "Retaining Customers With Shopping Convenience," Journal of Relationship Marketing, Vol. 8, No. 4, 2009, pp. 313-329.

[16] F. Clerfeuille and Y. Poubanne, "Differences in the Contributions of Elements of Service to Satisfaction, Com- mitment and Consumers Share of Purchase: A Study from the Tetraclass Model," Journal of Targeting, Vol. 1, 2002.

[17] A. W. Magi, "Share of Wallet in Retailing: The Effects of Customer Satisfaction, Loyalty Cards and Shopper Characteristics," Journal of Retailing, Vol. 79, No. 2, 2003, pp. 97-106. doi:10.1016/S0022-4359(03)00008-3

[18] P. Zhou and Y. Y. Hao, "The Customer Loyalty Measurement Model: Based on Two Dimensions of Attitudes And Wallet Share," Management Science, Vol. 21, No. 4, 2009, pp. 47-59.

[19] Hye-Young Kim and Min-Young Lee, "Emotional Loyalty and Share of Wallet: A Contingency Approach," Journal of Retailing and Consumer Services, Vol. 17, No. 5, 2010, pp. 333-339. doi:10.1016/j.jretconser.2010.03.014

[20] Perkins-Munn Tiffany, L. Aksoy, T. L. Keiningham and D. Estrin, "Actual Purchase as a Proxy for Share of Wallet," Journal of Service Research, Vol. 7, No. 3, 2005, pp. 245-256. doi:10.1177/1094670504271149

[21] J. X. Liu and M. G. Sun, "The Formation of Share of Wallet and Improving Strategy," Journal of Business Economics, Vol. 5, 2006, p. 74.

[22] R. Y. Du, W. A. Kamakura and C. F. Mela, "Size and Share of Customer Wallet," Journal of Marketing, Vol. 71, No. 2, 2007, pp. 94-113.

[23] C. Keenan, "8 Keys to Opening Door for More Wallet Share," American Banker, Vol. 175, No. 42, 2010, pp. 4-6.

[24] H. Landy, "Banks Retain Trust, Lose Wallet Share," American Banker, Vol. 174, No. 160, 2009, pp. 12-12.

[25] L. H. Eisenstaedt, "Maximizing your wallet share," $A c$ counting Today, No. 12, 2005, p. 29.

[26] A. Paswan, Pineda María de los Dolores Santarriaga and Ramirez Francisco Carlos Soto, "Small Versus Large Retail Stores in an Emerging Market-Mexico," Journal of Business Research, Vol. 63, No. 7, 2010, pp. 667-672. doi:10.1016/j.jbusres.2009.02.020

[27] P. C. Verhoef, "Understanding the Effect of Customer Relationship Management Efforts on Customer Retention and Customer Share Development," Journal of Marketing, Vol. 67, No. 4, 2003, pp. 30-45.

[28] J. Van Doorn and P. C. Verhoef, "Critical Incidents and the Impact of Satisfaction on Customer Share," Journal of Marketing, Vol. 72, No. 4, 2008, pp. 123-142. doi: $10.1509 /$ jmkg.72.4.123

[29] Davis-Sramek Beth, C. Droge and J. T. M. B. Myers, "Creating Commitment and Loyalty Behavior among Retailers: What Are the Roles of Service Quality and Satisfaction?" Academy of Marketing Science, Vol. 37, No.4, 2009, pp. 440-454.doi: 10.1007/s11747-009-0148-y

[30] F. F. Reichheld, and W. Earl Sasser, Jr. "Zero Defections: Quality Comes to Services," Harvard Business Review, Vol. 68, No. 5, 1990, pp. 105-111.

[31] R. N. Bolton, K. N. Lemon and P. C. Verhoef, "The Theoretical Underpinnings of Customer Asset Manage- 
ment: A Framework and Propositions for Future Research," Academy of Marketing Science, Vol. 32, No. 3, 2004, pp. 271-292. doi:10.1177/0092070304263341

[32] T. L. Keiningham, Perkins-Munn Tiffany, L. Aksoy and D. Estrin, "Does Customer Satisfaction Lead to Profitability? The Mediating Role of Share of Wallet," Managing Service Quality, Vol. 15, No. 2, 2005, pp. 172-181. doi:10.1108/09604520510585352

[33] B. Douglas and N. Das, "Linking Customer Management Effort to Customer Profitability in Business Markets," Journal of Marketing Research, Vol. 41, No. 4, 2004, pp. 433-447.

[34] A. W. Magi, "Share of Wallet in Retailing: The Effects of Customer Satisfaction, Loyalty Cards and Shopper Characteristics," Journal of Retailing, Vol. 79, No. 2, 2003, pp. 97-106. doi:10.1016/S0022-4359(03)00008-3

[35] R. Silvestro and S. Cross, "Applying the Service Profit Chain in a Retail Environment," International Journal of Service Industry Management, Vol. 11, No. 3, 2000, pp. 244-268. doi:10.1108/09564230010340760
[36] M. L. Cheng, "Experimental Research on Determinants of Customer Loyalty," Journal of Management Sciences, Vol. 6, No. 5, 2003, pp. 72-78

[37] Teck-Hua Ho, Young-Hoon Park and Yong-Pin Zhou, "Incorporating Satisfaction into Customer Value Analysis: Optimal Investment in Lifetime Value," Johnson School Research Paper Series No. 03-06.

[38] P. M. Doney and J. P. Cannon, "An Examination of the Nature of Trust in Buyer-Seller Relationships," Journal of Marketing, Vol. 61, No. 2, 1997, pp. 35-51. doi:10.2307/1251829

[39] Y. Liu, "Research on Evaluation of Customer Satisfaction of BPO Enterprise Based on Analytic Hierarchy Process," Economic Management, Vol. 24, No. 5, 2008, pp. 65-68.

[40] R. T. Rust, K. N. Lemon and V. A. Zeithaml, "Return on Marketing: Using Customer Equity to Focus Marketing Strategy," Journal of Marketing, Vol. 68, 2004, pp. 109-127.doi:10.1509/jmkg.68.1.109.24030 